BALDOTTO LEB; BALDOTTO MA. 2014. Adventitious rooting on the Brazilian red-cloak and sanchezia after application of indole-butyric and humic acids. Horticultura Brasileira 32: 434-439. DOI - http://dx.doi.org/10.1590/S0102-053620140000400010

\title{
Adventitious rooting on the Brazilian red-cloak and sanchezia after application of indole-butyric and humic acids
}

\author{
Lílian EB Baldotto; Marihus A Baldotto \\ UFV, Rod. LMG 818, km 06, 35690-000Florestal-MG; lilian.estrela@ufv.br; marihus@ufv.br
}

\begin{abstract}
Plant regulators, as well as bioactive fractions of the organic matter, can accelerate the development and increase the efficiency of adventitious rooting in ornamental plants. We evaluated rooting in the Brazilian red-cloak (Megaskepasma erythrochlamys) and sanchezia (Sanchezia nobilis) cuttings in response to application of indole-butyric acid (IBA) and humic acids (HA). Stem cuttings of both species treated with solutions of $0,250,500,1000,2000 \mathrm{mg} / \mathrm{L}$ of IBA and $0,10,20,30,40 \mathrm{mmol} / \mathrm{L}$ of $\mathrm{C}$ of HA were placed in 2.0 $\mathrm{L}$ plastic pots containing carbonized rice husk, kept in greenhouse. Survival of cuttings, number of leaves and shoot and root fresh and dry matter were evaluated 45 days after. Data were used to run an analysis of variance. We observed the average contrasts, calculated the regression equations and estimated the concentrations that provided the best efficiency in terms of root dry matter. For IBA, 185.4 and $66.8 \mathrm{mg} / \mathrm{L}$ were the concentrations that promoted the highest root dry matter accumulation in the Brazilian red-cloak and sanchezia, respectively, with increments of 140 and $22.5 \%$ in relation to the control. $\mathrm{HA}$, at $33.6 \mathrm{mmol} \mathrm{L}^{-1}$ of $\mathrm{C}$, increased shoot fresh and dry matter in the Brazilian red-cloak, but reduced root formation compared to the control. In sanchezia, HA at $19.5 \mathrm{mmol} / \mathrm{L}$ of $\mathrm{C}$ promoted increases of $35.9 \%$ in root dry matter in relation to the control. We concluded that IBA, in the abovementioned concentrations, increased adventitious rooting in cuttings of both the Brazilian red-cloak and sanchezia, while optimal doses of HA solutions are very likely to improve adventitious rooting in sanchezia, but not in the Brazilian red-cloak.
\end{abstract}

Keywords: Megaskepasma erythrochlamys, Sanchezia nobilis, vegetative propagation, humic substances, auxins.

\begin{abstract}
RESUMO
Enraizamento adventício de justícia vermelha e sanquésia usando ácidos indolbutírico e húmico

O enraizamento adventício de plantas ornamentais pode ser acelerado por meio da aplicação de fitorreguladores e também de frações ativas da matéria orgânica. $\mathrm{O}$ objetivo deste trabalho foi avaliar o enraizamento adventício de justícia vermelha (Megaskepasma erythrochlamys) e sanquésia (Sanchezia nobilis) em resposta à aplicação de concentrações de ácido indolbutírico (AIB) e ácido húmico $(\mathrm{AH})$. Estacas caulinares das duas espécies tratadas com soluções de 0, 250, 500, 1000, $2000 \mathrm{mg} / \mathrm{L}$ de AIB e 0, 10, 20, 30, $40 \mathrm{mmol} / \mathrm{L}$ de $\mathrm{C}$ de $\mathrm{AH}$ foram colocadas em vasos de plástico de 2,0 L, contendo casca-de-arroz carbonizada como substrato, mantidos em casa-de-vegetação. A sobrevivência das estacas, número de folhas e matéria fresca e seca da parte aérea e de raízes foram avaliadas 45 dias após. Os resultados foram submetidos à análise de variância. Foram observados os contrastes médios, calculadas as equações de regressão e estimadas as concentrações dos fitorreguladores de melhor eficiência em termos de matéria seca de raiz. As concentrações 185,4 e $66,8 \mathrm{mg} / \mathrm{L}$ de AIB promoveram os maiores acúmulos de matéria seca da raiz em estacas de justícia e sanquésia, respectivamente, com incrementos de 140 e 22,5\% em comparação ao controle. A aplicação de AH na concentração de 33,6 mmol/L de $\mathrm{C}$ promoveu aumento no acúmulo de matéria fresca e seca da parte aérea em justícia, mas diminuiu a formação de raízes em relação ao controle. Em sanquésia, a aplicação de AH na concentração de 19,5 $\mathrm{mmol} / \mathrm{Lde} \mathrm{C}$ promoveu incrementos de $35,9 \%$ no acúmulo de matéria seca da raiz em comparação ao controle. Concluiu-se que a aplicação de AIB nas concentrações citadas acima aumentou o enraizamento adventício de justícia e sanquésia e doses ótimas de soluções de $\mathrm{AH}$ provavelmente proporcionam aumentos no enraizamento adventício de sanquésia e diminuições em justícia.
\end{abstract}

Palavras-chave: Megaskepasma erythrochlamys, Sanchezia nobilis, propagação vegetativa, substâncias húmicas, auxinas.

(Recebido para publicação em 31 de maio de 2013; aceito em 5 de agosto de 2014)

(Received on May 31, 2013; accepted on August 5, 2014)

$\mathrm{B}$ razil has a large and expanding potential to become a major producer and exporter of flowers and ornamental plants (Junqueira \& Peetz, 2008), especially when it comes to tropical plants, which have a broad genetic diversity in the country and find favorable growing conditions (Anefalos et al., 2010; Vera, 2008). The Brazilian red-cloak (Megaskepasma erythrochlamys) and sanchezia (Sanchezia nobilis), from the
Acanthaceae family, are erect shrubs, 2-3 meter tall (Lorenzi \& Souza, 2008), are ornamental plants that can be used in gardens and parks, either as isolated plants or in patches, in tropical and subtropical conditions. Both species are 
propagated through vegetative means, mainly by stem cuttings, best results being observed with cuttings harvested after flowering and rooted in protected environments (Lorenzi \& Souza, 2008).

The propagation by cuttings favors the quick and massive production of plantlets with complete fidelity to the mother plant. However, for the propagation process to be successful, it is important to achieve a high rate of rooting. The main factors that influence adventitious rooting in cuttings are related to the propagation material (e.g. genotype, type of cutting) and the rooting environment (e.g. substrate, humidity) (Hartmann et al., 2011).

Growth regulators of the auxin type, such as the indole-butyric acid (IBA) accelerate the process of adventitious rooting and make room for a vigorous development of plantlets in many species, including several ornamental plants (Loss et al., 2009; Pizzatto et al., 2011). Nevertheless, IBA is an expensive chemical reagent produced by specialized companies. In addition, it presents toxicity to humans, causing skin irritation and eye and respiratory infection, if handled improperly (SigmaAldrich, 2014). It is also toxic to the environment, particularly aquatic environments (Sigma-Aldrich, 2014). Humic acids (HA), the bioactive fraction of the organic matter after humification, also promotes adventitious rooting in cuttings of ornamental plants (Baldotto et al., 2012), and with economic and environmental advantages in relation to IBA: HA are a renewable natural resource which can be extracted from different urban wastes such as garbage and sewage sludge (Canellas et al., 2000), as well as from agriculture residues, such as animal manures (Melo et al., 2008). However, plant response to HA application is not uniform and varies with the raw material which these compounds where extracted from and their concentration, and plant genotype (Baldotto et al., 2011, 2012).

$\mathrm{HA}$, the most stable reactive fraction of humic substances, have dark color and varied chemical structure, with high content of aromatic rings and carboxylic, phenolic and quinone functional groups (Baldotto et al., 2007;
Guerra et al., 2008). HA alter growth and development of various plants of agronomic interest, accelerating root growth and boosting plant biomass (Zandonadi et al., 2007; Baldotto et al., 2009; Lima et al., 2011; Arancón et al., 2012).

We aimed to study the adventitious rooting of apical stem cuttings of Brazilian red-cloak and sanchezia plants in response to the application of different concentrations of IBA and HA.

\section{MATERIAL AND METHODS}

Apical cuttings were taken from branches of the Brazilian red-cloak (Megaskepasma erythrochlamys) and sanchezia (Sanchezia nobilis) mother plants grown at the Universidade Federal de Viçosa, Campus Florestal. Cuttings were collected in September 2011 and standardized to $15-\mathrm{cm}$ length and two apical leaves cut crosswise in half.

The experimental matrix $[2 \mathrm{x}(5+5)]$ consisted of two ornamental species (the Brazilian red-cloak and sanchezia), five concentrations $(0,250,500,1000$, $2000 \mathrm{mg} / \mathrm{L}$ ) of indole-butyric acid (IBA) and five concentrations $(0,10,20,30$, $40 \mathrm{mmol} / \mathrm{L} \mathrm{C}$ ) of humic acids (HA) previously isolated from vermicompost by Baldotto et al. (2012). Cuttings were placed in $50 \mathrm{~mL}$ plastic cups containing HA solutions for 24 hours (Baldotto et al., 2009) and in those with IBA solutions for 10 seconds (Lima et al., 2008). Following, cuttings were transferred to $2.0 \mathrm{~L}$ black plastic pots filled with substrate (carbonized rice husk), and kept in greenhouse. The experimental units consisted of a fivecutting pot. The experiment was carried out in a randomized block design, with five replications, totaling 100 experimental units.

Forty-five days after, the following characteristics were assessed: number

Table 1. Means, average contrasts, relative increases, error mean square and coefficient of variation for survival of cuttings (SC), number of leaves (NL), leaf fresh (LFM) and dry matter (LDM), root fresh (RFM) and dry matter (RDM) of the Brazilian red-cloak plants in response to application of indole-butyric acid (IBA) and humic acids (HA), data from 5 replicates of 5 cuttings per pot [médias, contrastes, incrementos relativos, quadrado médio do resíduo e coeficiente de variação para sobrevivência das estacas (SC), número de folhas (NL), matérias fresca (LFM) e seca das folhas (LDM), matérias fresca (RFM) e seca das raízes (RDM) de plantas de justícia-vermelha em resposta à aplicação de ácido indol butírico (IBA) e ácidos húmicos (HA), dados de 5 repetições de 5 estacas por vaso]. Florestal, UFV, 2011.

\begin{tabular}{|c|c|c|c|c|c|c|}
\hline \multirow{2}{*}{ Treatments } & SC & NL & LFM & LDM & RFM & RDM \\
\hline & \multicolumn{2}{|c|}{ (unit) } & \multicolumn{4}{|c|}{ (g) } \\
\hline IBA0 & 5 & 27 & 8.92 & 1.26 & 1.83 & 0.15 \\
\hline IBA250 & 5 & 29 & 10.59 & 1.77 & 4.02 & 0.36 \\
\hline IBA500 & 5 & 31 & 13.89 & 1.92 & 3.83 & 0.35 \\
\hline IBA 1000 & 5 & 26 & 11.17 & 1.71 & 2.68 & 0.25 \\
\hline IBA2000 & 5 & 26 & 12.84 & 1.79 & 2.98 & 0.30 \\
\hline HA0 & 5 & 26 & 18.81 & 2.45 & 4.56 & 0.40 \\
\hline HA10 & 5 & 27 & 19.58 & 2.56 & 3.16 & 0.33 \\
\hline HA20 & 5 & 30 & 11.28 & 1.71 & 1.26 & 0.12 \\
\hline HA30 & 5 & 27 & 9.67 & 1.58 & 1.02 & 0.10 \\
\hline HA40 & 5 & 34 & 10.63 & 1.62 & 1.52 & 0.13 \\
\hline $\begin{array}{l}\text { Contrast } \\
\text { (IBA x HA) }\end{array}$ & $-0.80^{0}$ & 5.60 & $12.57^{*}$ & $1.06^{0}$ & -3.80 & -0.32 \\
\hline $\mathrm{RI}(\%)^{1}$ & 3.23 & 3.89 & 17.96 & 14.68 & 24.79 & 22.89 \\
\hline MS & 0.10 & 22.77 & 13.39 & 0.25 & 3.12 & 0.23 \\
\hline CV (\%) & 6.59 & 16.89 & 28.73 & 27.28 & 65.73 & 62.07 \\
\hline
\end{tabular}

$*$ and ${ }^{0}=$ significant at $\mathrm{p}<0.05$ and 0.01 respectively (significativo, $\mathrm{p}<0,05$ e 0,01 , respectivamente); Relative increases $=100(\mathrm{x}-\mathrm{y}) / \mathrm{y}$, where $\mathrm{x}$ and $\mathrm{y}$ correspond to the means for the treatment with the highest and lowest values respectively (incrementos relativos $=100$ $(\mathrm{x}-\mathrm{y}) / \mathrm{y}$, sendo $\mathrm{x}$ e $\mathrm{y}$ as médias dos tratamentos de maior e menor valor respectivamente). 
of surviving cuttings per pot (SC), total number of leaves per experimental unit (NL), leaf fresh (LFM) and dry matter (LDM) and root fresh (RFM) and dry matter (RDM). Dry matter was obtained by drying leaves and roots in an oven under forced ventilation at $60^{\circ} \mathrm{C}$, for seven days.

Results were used to run an analysis of variance. The effects of treatments were deployed unfolded on average contrasts, as indicated by Alvarez \& Alvarez (2006). We also adjusted regression equations using the means of the characteristics studied and IBA and HA concentrations. The F test was applied to the unfolded factors at 10,5 and $1 \%$ of probability. The slopes of the regression equations were tested when presented coefficient of determination greater than 0.60 . The regression equations were used to estimate the concentration of maximum physical efficiency for root dry matter as function of IBA and HA concentrations.

\section{RESULTS AND DISCUSSION}

In this study we established the concentrations of indole-butyric acid (IBA) and humic acids (HA) that promoted growth and adventitious rooting of cuttings of the Brazilian redcloak and sanchezia, aiming at speeding up and improving the efficiency of vegetative propagation in these species.

The application of mounting concentrations of IBA and HA significantly alter rooting performance and shoot growth in cuttings of the Brazilian red-cloak and sanchezia (Tables 1 and 2). The same tables contain the average contrasts for qualitative data. Leaf fresh (LFM) and dry matter (LDM) in plants of the Brazilian red-cloak treated with HA increased significantly when compared to those treated with IBA, with LFM and LDM values 17.9 and $14.6 \%$ higher in the former than in the later (Table 1). Biomass accumulation in shoots in response to HA application in nursery material had already been reported for other species of agronomic interest such as pineapple (Baldotto et al., 2009), croton, and hibiscus (Baldotto et al.,

Table 2. Means, average contrast, relative increases, error mean square and coefficient of variation for survival of cuttings (SC), number of leaves (NL), leaf fresh (LFM) and dry matter (LDM), root fresh (RFM) and dry matter (RDM) of sanchezia plants in response to application of indole-butyric acid (IBA) and humic acids (HA), data from 5 replicates of 5 cuttings per pot [médias, contrastes, incrementos relativos, quadrado médio do resíduo e coeficiente de variação para sobrevivência das estacas (SC), número de folhas (NL), matérias fresca (LFM) e seca das folhas (LDM), matérias fresca (RFM) e seca das raízes (RDM) de plantas de justícia-vermelha em resposta à aplicação de ácido indol butírico (IBA) e ácidos húmicos (HA), dados de 5 repetições de 5 estacas por vaso]. Florestal, UFV, 2011.

\begin{tabular}{|c|c|c|c|c|c|c|}
\hline \multirow{2}{*}{ Treatments } & SC & NL & LFM & LDM & RFM & RDM \\
\hline & \multicolumn{2}{|c|}{ (unit) } & \multicolumn{4}{|c|}{ (g) } \\
\hline IBA0 & 5 & 29 & 12.54 & 1.95 & 10.60 & 1.03 \\
\hline IBA250 & 5 & 27 & 14.11 & 2.00 & 12.99 & 1.22 \\
\hline IBA500 & 5 & 25 & 12.99 & 1.89 & 11.91 & 1.16 \\
\hline IBA 1000 & 5 & 28 & 13.30 & 1.98 & 13.84 & 1.28 \\
\hline IBA2000 & 5 & 28 & 12.47 & 1.78 & 15.15 & 1.25 \\
\hline HA0 & 4 & 23 & 9.57 & 1.43 & 9.43 & 0.62 \\
\hline HA10 & 4 & 24 & 9.07 & 1.29 & 8.05 & 0.75 \\
\hline HA20 & 5 & 29 & 11.80 & 1.78 & 8.72 & 0.93 \\
\hline HA30 & 4 & 24 & 9.67 & 1.43 & 7.22 & 0.70 \\
\hline HA40 & 4 & 24 & 8.41 & 1.22 & 5.72 & 0.63 \\
\hline $\begin{array}{l}\text { Contrast } \\
\text { (IBA x HA) }\end{array}$ & $-3.00 * *$ & $-13.80^{0}$ & $-16.89 * *$ & $-2.43 * *$ & $-25.34 * *$ & $-2.31^{0}$ \\
\hline RI (\%) & 12.00 & 10.03 & 25.83 & 25.33 & 39.29 & 38.94 \\
\hline MS & 0.40 & 27.01 & 12.91 & 0.28 & 11.57 & 0.92 \\
\hline $\mathrm{CV}(\%)$ & 13.45 & 19.88 & 31.54 & 31.58 & 32.82 & 31.72 \\
\hline
\end{tabular}

$*$ and ${ }^{0}=$ significant at $\mathrm{p}<0.05$ and 0.01 respectively (significativo, $\mathrm{p}<0,05$ e 0,01 , respectivamente); Relative increases $=100(\mathrm{x}-\mathrm{y}) / \mathrm{y}$, where $\mathrm{x}$ and $\mathrm{y}$ correspond to the means for the treatment with the highest and lowest values respectively [incrementos relativos $=100$ $(\mathrm{x}-\mathrm{y}) / \mathrm{y}$, sendo $\mathrm{x}$ e $\mathrm{y}$ as médias dos tratamentos de maior e menor valor respectivamente].

2012). However, in eucalyptus there was no significant response (Pinheiro et al., 2010), findings that encourages research towards elucidating HA mechanisms of action if these compounds are intended to be developed into a sustainable agricultural input.

HA mode of action was not investigated in this work. However, other studies have suggested the existence of different mechanisms (Zandonadi et al., 2013). It has been proposed that HA stimulate root growth in an auxin like manner, i.e., by modulating the $\mathrm{H}^{+}$-ATPases in the cell membrane (Canellas et al., 2002; Façanha et al., 2002). ATPases are enzymes that acidify the apoplast, and thus activate enzymes that degrade the cell wall and make cells more susceptible to the action of the vacuolar turgor pressure, resulting in cell expansion (Rayle \& Cleland, 1992). $\mathrm{HA}$ also act in the regulation of nutrient uptake (Nardi et al., 2002; Sondergaard et al., 2004; Lima et al., 2011) and further increases in the accumulation of photosynthesizing pigments (Baldotto et al., 2009). Such mechanisms may explain the growth in shoot fresh and dry matter we observed in cuttings of the Brazilian red-cloak.

IBA promoted increments in all traits in sanchezia (Table 2). Survival of cuttings (SC), number of leaves (NL), leaf fresh (LFM) and dry matter (LDM), and root fresh (RFM) and dry matter (RDM) had increases of 12 , 10, 26, 25, 39 and 39\% respectively, compared to the treatment with HA. IBA is a plant regulator with typical auxin hormonal action. It is commercially available in liquid and solid forms and it is used to stimulate adventitious root development, since it favors the formation of meristematic tissue and cell elongation (Hartmann et al., 2011). IBA efficiency in promoting adventitious rooting in cuttings of ornamental plants 
Table 3. Regression equations for survival of cuttings (SC), number of leaves (NL), leaf fresh (LFM) and dry matter (LDM), root fresh (RFM) and dry matter (RDM) of the Brazilian red-cloak and sanchezia plants in response to application of indole-butyric acid (IBA) and humic acids (HA) \{equações de regressão para sobrevivência das estacas (SC), número de folhas (NL), matérias fresca (LFM) e seca das folhas (LDM), matérias fresca (RFM) e seca das raízes (RDM) de plantas de justícia-vermelha em resposta à aplicação de ácido indol butírico (IBA) e ácidos húmicos (HA)\}. Florestal, UFV, 2011.

\begin{tabular}{|c|c|c|c|}
\hline \multirow{2}{*}{ Characteristics } & \multirow{2}{*}{ Unfolding } & Regression equation & \multirow{2}{*}{$\mathbf{R}^{2}$} \\
\hline & & $\begin{array}{r}\text { The Brazilian red-cloak } \\
\end{array}$ & \\
\hline \multirow{2}{*}{ SC (unit) } & IBA & $\hat{y}=4.990+0.000088 x-0.00000009 * x^{2}$ & 0.9863 \\
\hline & HA & $\hat{y}=4.596+0.273 * x^{0.5}-0.04288 x$ & 0.9832 \\
\hline \multirow{2}{*}{ NL (unit) } & IBA & $\hat{y}=26.889+0.0165 x-0.000026 x^{2}+0.000000009 * x^{3}$ & 0.8871 \\
\hline & HA & $\hat{y}=26.071+0.5607 x-0.0391 x^{2}-0.00075^{\circ} x^{3}$ & 0.8241 \\
\hline \multirow{2}{*}{$\operatorname{LFM}(\mathrm{g})$} & IBA & $\hat{y}=8.535+0.018 x-0.000022 x^{2}+0.000000007^{\circ} x^{3}$ & 0.8263 \\
\hline & HA & $\hat{y}=20.263-0.4651 x+0.00505^{(\mathrm{P}<0.20)} \mathrm{x}^{2}$ & 0.7909 \\
\hline \multirow{2}{*}{$\operatorname{LDM}(g)$} & IBA & $\hat{y}=1.291+0.0379^{(\mathrm{P}<0.15)} \mathrm{x}^{0.5}-0.000625 \mathrm{x}$ & 0.8506 \\
\hline & HA & $\hat{y}=2.591-0.0424 x+0.000401^{(P<0.21)} \mathrm{x}^{2}$ & 0.7851 \\
\hline \multirow{2}{*}{ RFM (g) } & IBA & $\hat{y}=1.818+0.3825 x^{0.5}-0.0188 x+0.00024^{(P<0.14)} x^{1.5}$ & 0.9869 \\
\hline & HA & $\hat{y}=4.731-0.2379 x+0.3889 * x^{2}$ & 0.9689 \\
\hline \multirow{3}{*}{ RDM (g) } & IBA & $\hat{y}=0.149+0.0349 x^{0.5}-0.00169 x+0.00002^{(P<0.15)} x^{1.5}$ & 0.9867 \\
\hline & HA & $\hat{y}=0.424-0.0187 x+0.000278^{\circ} x^{2}$ & 0.8980 \\
\hline & \multicolumn{3}{|c|}{$\begin{array}{r}\text { Sanchezia } \\
\end{array}$} \\
\hline \multirow{2}{*}{ SC (unit) } & IBA & $\hat{\mathrm{y}}=\overline{\mathrm{y}}=5$ & \\
\hline & HA & $\hat{y}=\bar{y}=4$ & \\
\hline \multirow{2}{*}{ NL (unit) } & IBA & $\hat{y}=29.054-1.671^{(P<0.29)} \mathrm{x}^{0.5}+0.248 \mathrm{x}$ & 0.7063 \\
\hline & HA & $\hat{y}=\bar{y}=23$ & \\
\hline \multirow{2}{*}{$\operatorname{LFM}(\mathrm{g})$} & IBA & $\hat{\mathrm{y}}=12.581+0.7719^{(\mathrm{P}<0.26)} \mathrm{x}^{0.5}-0.125 \mathrm{x}$ & 0.7392 \\
\hline & HA & $\hat{y}=0.9551-3.5322 x^{0.5}+1.6749 x-0.1821^{(\mathrm{P}<0.25)} \mathrm{x}^{1.5}$ & 0.7523 \\
\hline \multirow{2}{*}{$\operatorname{LDM}(\mathrm{g})$} & IBA & $\hat{y}=\bar{y}=1.917$ & \\
\hline & HA & $\hat{y}=1.432-0.01356 x-0.0017^{\circ} x^{2}$ & 0.7381 \\
\hline \multirow{2}{*}{ RFM (g) } & IBA & $\hat{y}=10.73+0.1878^{(\mathrm{P}<0.18)} \mathrm{x}^{0.5}+0.7142 \mathrm{x}$ & 0.8159 \\
\hline & HA & $\hat{y}=9.136-0.0136 x-0.0017^{\circ} x^{2}$ & 0.8769 \\
\hline \multirow{2}{*}{ RDM (g) } & IBA & $\hat{y}=1.039+0.0556^{(\mathrm{P}<0.17)} \mathrm{x}^{0.5}-0.0034 \mathrm{x}$ & 0.8316 \\
\hline & HA & $\hat{\mathrm{y}}=0.614+0.0231 \mathrm{x}-0.00059^{(\mathrm{P}<0.12)} \mathrm{x}^{2}$ & 0.7433 \\
\hline
\end{tabular}

${ }^{*},{ }^{\circ}$ and ${ }^{\mathrm{P}}=$ significant at $\mathrm{p}<0.10,0.05$ and 0.01 respectively (significativo, $\mathrm{p}<0,10,0,05$ e 0,01 , respectivamente).

have been reported to allamanda (Loss et al., 2008; Pereira et al., 2012), croton (Baldotto et al., 2012), oleander (Pivetta et al., 2012), hibiscus (Pizzatto et al., 2011; Baldotto et al., 2012) and wax mallow (Loss et al., 2009). Besides stimulating root formation, exogenous application of auxins also increases rooting speed and uniformity (Hartmann et al., 2011), contributing to production of vigorous plantlets in less time. However, IBA is potentially harmful to health. It presents acute toxicity when ingested and causes a irritation of skin, eyes and the respiratory tract if inhaled (Sigma-Aldrich, 2014).
Once the regression equations for plant growth characteristics as function of IBA and HA concentrations were obtained (Table 3), we calculated the concentrations of maximum physical efficiency for RDM for the Brazilian red-cloak and sanchezia (Table 4).

In plants of the Brazilian red-cloak, maximum physical efficiency for RDM was achieved at $185.42 \mathrm{mg} / \mathrm{L}$ of IBA and $33.6 \mathrm{mmol} / \mathrm{L}$ of $\mathrm{C}$ of HA (Table 4 ). Such IBA concentration resulted in an increment $140 \%$ in RDM in relation to the control. As no effect of HA has been significant, HA should not be used in the Brazilian red-cloak to replace auxins.
IBA, on its turn, resulted in significant increases in root growth, corroborating Ferriani et al. (2006), who affirmed that IBA is one of the most effective rooting inducing substances.

In sanchezia, the maximum physical efficiency for MSR was achieved with $66.8 \mathrm{mg} / \mathrm{L}$ of IBA and $19.5 \mathrm{mmol} / \mathrm{L}$ of C for HA (Table 4), which resulted in root dry matter 35.9 and $22.3 \%$ higher than the control, respectively (Table 4). These results allow the conclusion that HA can be an alternative to the use of synthetic auxin in sanchezia. Baldotto et al. (2012) also observed HA satisfactory results in the adventitious 
Table 4. Root dry matter (RDM) of the Brazilian red-cloak and sanchezia plants on condition of maximum physical efficiency (MFE) in response to the application of indole-butyric acid (IBA) and humic acids (HA) (matéria seca da raiz (RDM) de plantas de justícia-vermelha e de sanquésia na condição de máxima eficiência física (MEF) em resposta à aplicação de ácido indol butírico (IBA) e ácidos húmicos (HA)\}. Florestal, UFV, 2011.

\begin{tabular}{lccccc}
\hline Species & Treatment & $\begin{array}{c}\text { MFE Concentration } \\
\text { for RDM }\end{array}$ & $\begin{array}{c}\text { Average for } \\
\text { the control (g) }\end{array}$ & $\begin{array}{c}\text { Average for } \\
\text { MFE }(\mathbf{g})\end{array}$ & $\begin{array}{c}\text { Difference } \\
(\mathbf{\%})\end{array}$ \\
\hline The Brazilian & IBA & $185.42 \mathrm{mg} / \mathrm{L}$ & 0.15 & 0.36 & 140 \\
red-cloak & HA & $33.63 \mathrm{mmol} / \mathrm{L}$ & 0.40 & 0.11 & -72 \\
\hline \multirow{2}{*}{ Sanchezia } & IBA & $66.85 \mathrm{mg} / \mathrm{L}$ & 1.03 & 1.27 & 22 \\
& HA & $19.58 \mathrm{mmol} / \mathrm{L}$ & 0.62 & 0.84 & 36 \\
\hline
\end{tabular}

Difference $=100(\mathrm{x}-\mathrm{y}) / \mathrm{y}$, where $\mathrm{x}$ and $\mathrm{y}$ correspond to the means for the treatment with the highest and lowest values respectively [diferença $=100(\mathrm{x}-\mathrm{y}) / \mathrm{y}$, sendo $\mathrm{x}$ e $\mathrm{y}$ as médias dos tratamentos de maior e menor valor respectivamente].

rooting of hibiscus. There are several studies with horticultural crops such as the perennial ryegrass (Silva et al., 2000), caisin (Wangen et al., 2013), gladiolus (Baldotto \& Baldotto, 2013), melon (Pinto et al., 2008) and tomato (Bernardes et al., 2011; Lima et al., 2011) reporting positive effects on the development and production of plants grown in open field and protected environments in response to application of humic substances, either as isolate compounds or as constituents of organic fertilizers or biofertilizers. These studies point to a potential new technological option for farmers, especially for those seeking a more sustainable agriculture, in which the use of synthetic inputs is reduced, while the recycling of organic waste is levered.

Our results indicate that the application of IBA and HA in apical cuttings of the Brazilian red-cloak and sanchezia, in the concentrations evaluated, accelerates plantlet production. This result is relevant, since the efficiency of the vegetative propagation interferes on the production and commercialization of ornamental plants.

\section{ACKNOWLEDGEMENTS}

To CNPq, FAPEMIG andFUNARBE for financial support.

\section{REFERENCES}

ALVAREZ VVH; ALVAREZ GAM. 2006. Comparações de médias ou testes de hipóteses? Contrastes! Boletim Informativo da Sociedade Brasileira de Ciência do Solo. 31: $24-34 \mathrm{p}$.

ANEFALOS LC; TOMBOLATO AFC; RICORDI A. 2010. Panorama atual e perspectivas futuras da cadeia produtiva de flores tropicais: o caso do antúrio. Revista Brasileira de Horticultura Ornamental 16: 107-111.

ARANCON NQ; PANT A; RADOVICH T; HUE NV; POTTER JK; CONVERSE CE. 2012. Seed germination and seedling growth of tomato and lettuce as affected by vermicompost water extracts (Teas). HortScience 47: 1722-1728.

BALDOTTO LEB; BALDOTTO MA; GIRO VB; CANELLAS LP; OLIVARES FL; BRESSANSMITH R. 2009. Desempenho do abacaxizeiro 'Vitória' em resposta à aplicação de ácidos húmicos durante a aclimatação. Revista Brasileira de Ciência do Solo 33: 979-990.

BALDOTTO LEB; BALDOTTO MA; SOARES RR; MARTINEZ HEP; VENEGAS VHA. 2012. Adventitious rooting in cuttings of croton and hibiscus in response to indolbutyric acid and humic acid. Revista Ceres 59: 476483.

BALDOTTO MA; BALDOTTO LEB. 2013. Gladiolus development in response to bulb treatment with different concentrations of humic acids. Revista Ceres 60: 138-142.

BALDOTTO MA; CANELLAS LP; CANELA MR; SIMÕES ML; MARTIN-NETO L; FONTES MPF; VELLOSO ACX. 2007. Propriedades redox e grupos funcionais de ácidos húmicos isolados de adubos orgânicos. Revista Brasileira de Ciência do Solo 31: 465-475.

BALDOTTO MA; MUNIZ RC; BALDOTTO LEB; DOBBSS LB. 2011. Root growth of Arabidopsis thaliana treated with humic acids isolated from typical soils of Rio de Janeiro state, Brazil. Revista Ceres 58: 504-511.

BERNARDES JM; REIS JMR; RODRIGUES JF. 2011. Efeito da aplicação de substância húmica em mudas de tomateiro. Global Science and Technology 4: 92-99.

CANELLAS LP; FAÇANHA AO; FAÇANHA AR; OLIVARES FL. 2002. Humic acids isolated from earthworm induces root mitotic sites and plasma membrane $\mathrm{H}^{+}$-ATPase. Plant Physiology 30: 1951-1957.

CANELLAS LP; SANTOS GA; MORAES AA;
RUMJANEK VM; OLIVARES FL. 2000. Avaliação de características de ácidos húmicos de resíduos de origem urbana: I. Métodos espectroscópicos (UV-Vis, IV, RMN ${ }^{13} \mathrm{C}-\mathrm{CP} /$ MAS) e microscopia eletrônica de varredura. Revista Brasileira de Ciência do Solo 24: 741-750.

FAÇANHA AR; FAÇANHA ALO; OLIVARES FL; GURIDI F; SANTOS GA; VELLOSO ACX; RUMJANEK VM; BRASIL F; SCHRIPSEMA J; BRAZ-FILHO R; OLIVEIRA MA; CANELLAS LP. 2002. Bioatividade de ácidos húmicos: efeito sobre o desenvolvimento radicular e sobre a bomba de prótons da membrana plasmática. Pesquisa Agropecuária Brasileira 37: 1301-1310.

FERRIANI AP; BORTOLINI MF; ZUFFELLATO-RIBAS KC; KOEHLER HS. 2006. Propagação vegetativa de estaquia de azaléia arbórea (Rhododendron thomsonii). Semina: Ciências Agrárias 27: 35-42.

GUERRA JCM; SANTOS GA; SILVA LS; CAMARGO FAO. 2008. Macromoléculas e substâncias húmicas. In: SANTOS GA (ed). Fundamentos da matéria orgânica do solo: Ecossistemas tropicais \& subtropicais. 2.ed. Porto Alegre: Metrópole. p.19-26.

HARTMANN HT; KESTER DE; DAVIES RT; GENEVE RL. 2011. Plant propagation: principles and practices. $8^{\mathrm{a}}$ ed. New Jersey: Prentice Hall. 915p.

JUNQUEIRA HA; PEETZ MS. 2008. Mercado interno para os produtos da floricultura brasileira: características, tendências e importância sócio-econômica recente. Revista Brasileira de Horticultura Ornamental 14: 37-52.

LIMA AA; ALVARENGA MAR; RODRIGUES L; CARVALHO JG. 2011. Concentração foliar de nutrientes e produtividade de tomateiro cultivado sob diferentes substratos e doses de ácidos húmicos. Horticultura Brasileira 29: 63-69.

LIMA DM; SILVA CL; RITTER M; BIASI LA; ZANETTE F; ZUFFELLATO-RIBAS KC. 2008. Substratos e auxinas no enraizamento de estacas caulinares de espinheira-santa. Scientia Agraria 9: 85-89.

LORENZI HE; SOUZA HM. 2008. Plantas ornamentais no Brasil: arbustivas, herbáceas e trepadeiras. $4^{\mathrm{a}} \mathrm{ed}$. Nova Odessa: Instituto 
Plantarum. 1088p.

LOSS A; TEIXEIRA MB; ASSUNÇÃO GM; HAIM PG; LOUREIRO DC; SOUZA JR. 2008. Enraizamento de estacas de Allamanda cathartica tratadas com ácido indol-butírico (AIB). Revista Brasileira de Ciências Agrárias 3: 313-316.

LOSS A; TEIXEIRA MB; SANTOS TJ; GOMES VM; QUEIROZ LH. 2009. Indução do enraizamento em estacas de Malvaviscus arboreus com diferentes concentrações de ácido indol-butírico (AIB). Acta Scientiarum Agronomy 31: 269-273.

MELO LCA; SILVA CA; DIAS BO. 2008. Caracterização da matriz orgânica de resíduos de origens diversificadas. Revista Brasileira de Ciência do Solo 32: 101-110.

NARDI S; PIZZEGHELLO D; MUSCOLO A; VIANELLO A. 2002. Physiological effects of humic substances in higher plants. Soil Biology and Biochemistry 34: 1527-1537.

PEREIRA HAP; COUTINHO FS; SILVA RAC; LOSS A. 2012. Desenvolvimento de estacas de alamanda amarela sob diferentes concentrações de ácido indolbutírico. Comunicata Scientiae 3: 16-22.

PINHEIRO GL; SILVA CA; NETO EF. 2010. Crescimento e nutrição de clone de eucalipto em resposta à aplicação de concentrações de c-ácido húmico. Revista Brasileira de Ciência do Solo 34: 1217-1229.

PINTO JM; GAVA CAT; LIMA MAC; SILVA AF; RESENDE GM. 2008. Cultivo orgânico de meloeiro com aplicação de biofertilizantes e doses de substância húmica via fertirrigação. Revista Ceres 55: 280-286.

PIVETTA KFP; PEDRINHO DR; FÁVERO S; BATISTA GS; MAZZINI RB. 2012. Época de coleta e ácido indolbutírio no enraizamento de estacas de espirradeira (Nerium oleander). Revista Árvore 36: 17-23.

PIZZATTO M; WAGNER JÚNIOR A; LUCKMANN D; PIROLA K; CASSOL DA; MAZARO SM. 2011. Influência do uso do AIB, época de coleta e tamanho de estaca na propagação vegetativa de hibisco por estaquia. Revista Ceres 58: 4877-4892.

RAYLE DL; CLELAND RE. 1992 The acid growth theory of auxin-induced cell elongation is alive and well. Plant Physiology 99: 12711274.

SIGMA-ALDRICH. 2014, January, 05. Ficha de informação de segurança de produtos químicos. Available in: http://www. sigmaaldrich.com/catalog/product/sigma/ i5386? lang $=$ pt\&region $=\mathrm{BR}$

SILVA RM; JABLONSKI A; SIEWERDT L; SILVEIRA JÚNIOR P. 2000. Desenvolvimento das raízes do azevém cultivado em solução nutritiva completa adicionada de substâncias húmicas, sob condições de casa de vegetação. Revista Brasileira de Zootecnia, 29: 16231631.

SONDEGAARD TE; SCHULZAA; PALMGREN MG. 2004. Energization of transport processes in plants. Roles of plasma membrane $\mathrm{H}+-$ ATPase. Plant Physiology 136: 2475-2482.

VERA RM. 2008. Diagnóstico do mercado de flores tropicais. Revista Brasileira de Horticultura Ornamental 14: 35-36.

WANGEN DRB; MENDES LF; SAGATA E; SILVA HC; SHIMAMOTO GF. 2013. Fertilizante orgânico na produção de couve-daMalásia, Brassica chinensis var. parachinensis. Enciclopédia Biosfera 9: 1429-1435.

ZANDONADI DB; CANELLAS LP; FAÇANHA AR. 2007. Indolacetic and humic acids induce lateral root development through a concerted plasmalemma and tonoplast $\mathrm{H}^{+}$pumps activation. Planta 225: 1583-1595.

ZANDONADI DB; SANTOS MP; BUSATO JG; PERES LEP; FAÇANHA AR. 2013. Plant physiology as affected by humified organic matter. Theoretical and Experimental Plant Physiology 25: 12-25. 